\title{
OUTCOME BASED LEARNING: AN ANALYSIS OF IMPACT ON ACADEMIC ACHIEVEMENT AMONG SCHOOL STUDENTS
}

\author{
Prashant Thote ${ }^{*}{ }^{凶}$, Gowri. S 2 \\ *1, 2 Gyanodaya Vidya Mandir, India
}

DOI: https://doi.org/10.29121/granthaalayah.v8.i11.2020.2222

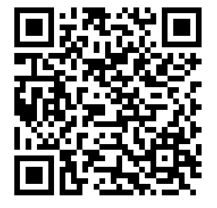

Article Type: Research Article

Article Citation: Prashant Thote, and Gowri. S. (2020). OUTCOME

BASED LEARNING: AN ANALYSIS

OF IMPACT ON ACADEMIC

ACHIEVEMENT AMONG SCHOOL

STUDENTS. International Journal of

Research -GRANTHAALAYAH,

8(11), 89-94.

https://doi.org/10.29121/granthaa

layah.v8.i11.2020.2222

Received Date: 25 October 2020

Accepted Date: 28 November 2020

Keywords:

Effectiveness

Model

Chemistry

Crystal Lattice and Learning

\begin{abstract}
The present century belongs to Science and Technology. Scientific knowledge is valued across the globe and great emphasis is on scientific attitude towards all fields of life. The purpose of education of Science school is to lead the nation to collaborate and compete with rest of the world. The students face difficulty in studying Chemistry due to its abstract nature of concepts. To address this issue, students are taught solid state Chemistry by using computer-based models of unit cells and the crystal lattices. The present study is experimental in nature. Total 60 students participate in the study. Samples are distributed in two groups (study group and control group). Data is collected by using question paper. The Chemistry of solid state is taught to the experimental group by using model based on computer and control group is taught by using traditional chalk and board methodology. The instrument is validated by its content and is consulted by an expert. The instrument reliability of is analyzed by applying t-test. Result of the research reveals that the computer-based model on crystal lattices and unit cell is more effective than conventional model in learning and the academic achievement of the students in Chemistry. The t-test proves that the $t$-value 0.691 is substantial with $p(p<0.05)$. Based on the findings of the present study the computer-based model of unit cell and crystal lattice is an effective teaching tool for learning and to improve the academic achievement in Chemistry.
\end{abstract}

\section{INTRODUCTION}

"Just because something is difficult; doesn't mean you shouldn't try, it just mean you should try harder"

- unknown

The objective of Science teaching is the involvement and understanding of the process of Science. The effective use of teaching tool is a pre-requisite in class room instructions. The concrete experiencing is crucial to develop conceptual understanding. The essence of teaching Science includes involvement and understanding of Science process. Teachers are in central position and an efficient teacher has the following responsibilities:

- Professional and scientific competencies: Science is an activity-based approach in class room instructions. The focus is on continuous professional development and scientific competence.

- Teachers must have knowledge about students' attitude and capabilities to select appropriate content for classroom instructions.

- Teachers must be able to facilitate teaching-learning and evidence-based learning.

(C) 2020 The Author(s). This is an open access article distributed under the terms of the Creative Commons Attribution License, which permits unrestricted use, distribution, and reproduction in any medium, provided the original author and source are credited. 
Chemistry plays a vital role in day to day life. The clothes we wear food we eat, building materials, yielding productivity of agriculture and medicines we require to maintain health and human necessitates all depend upon the knowledge of Chemistry. Tremendous development of Science and technology happens with the collaboration with Chemistry. Development of Chemistry makes advancement of communication, space, travel, agriculture and so many fields.

Learning experience is a joyful that motivates learners for the conceptual understanding and nurtures scientific attitude. Cognitive development is related with the learning process in formal educational system. The effective learning processes are meaningful and are created by teachers with appropriate learning approach, attitude and provide motivation to school students. Joyful learning is adopted for the development of psychological and cognitive domains by providing positive simulation and learning atmosphere. It is expected that the teaching learning process is done in a relaxed, carefree and motivating environment.

The Chemistry of solid state is a part of the curriculum for All India Senior Secondary School Examination. It is crucial to study the crystalline compound due to its interesting electrical, magnetic and other physical characteristics such as shapes, hardness etc. The long range arrangement of repeating units in crystalline structure are represented by single unit called unit cell and are illustrated by two dimensional structures. In classroom situation the most common challenge is the explanation of formation of different lattice structure in the stacking pattern of atoms/ions/ molecules/unit cell in crystal lattices.

The most common approach that are used in classroom instructions are: labeling the different particle layers with alphabets "abc" and listing the stacking pattern with types of alternative layers ("ab" and "abc"). Commonly used stacking pattern in teaching-learning by me is "ab"- for primitive cubic unit cell and "abab" for body-centered unit cell and "abab" in hexagonal closed packing crystal lattice. The unit cell simple cubic and body centered cubic crystal lattice arises from two dimensional layers with sequence and face centered unit cell and hexagonal closed packing crystal lattice arises from two dimensional layer with rhombus.

Teachers face difficulty in explaining three dimensional crystal lattices and its arrangements. The bigger challenges are in explaining lattices structure with counting particles/atoms/ions/molecules in each unit cell. Simple cubic unit cell represents single cube with eight atoms (1/8) like spear at each corner. In classroom instruction students do not get clear conceptual understanding of where the atoms or part of atoms come from. When eight full spheres are used to represent the unit cell, the misconception of unit cell consisting of eight atoms is common among students.

To address this issue, as a teacher I am using various approach such as handmade model of balls, handmade model of waste paper. In this paper attempt is made to develop the model of unit cell and crystal lattice by using two dimensional sketches, model kit, animation and three dimensional printed structure of unit cell and crystal lattices. It is an interactive teaching aid to provide direct link between unit cell representation and crystal lattice structure. Model offers visualization of various stacking pattern to give different types of unit cell -primitive, body centered and hexagonal close packing. The model design is an extended structure to foster the conceptual understanding of coordination number, shared atoms/ions/molecules between neighbouring unit cells. The model provides visualization of crystalline lattice structure of ionic compound and provides valuable insight of connection between the empirical formula and the extended structure.

\section{Model}

The model provides learners the dynamic view, manipulate and relate multiple representations of structural lattices. It also provides visualization of unit cell (primitive and face centered). It exhibits primary-atomic and crystalline structure such as primitive cubic, face centered, body centered, close cubic packing and hexagonal close packing. The structure can be rotated in 360 degrees and in all three dimensions it can be viewed at various magnifications. The false colour is used to illustrate the repeating layers.

The model fosters students in enhancing their knowledge, skills, competence and conceptual understanding of repetitive unit and 3-D (three dimensional) structures of crystal lattice and packing efficiency. Sliced apart atoms in unit cell picture correlates the extended structure with spherical representation is not essentially intuitive. The unit cell model allows students to dynamically relate two dimensional representations to each other. Successive explanation permits the user to observe individual unit cell and relate with one another. The crystal lattice structure may be zoomed to imagine the geometric impact of an individual piece of unit/atom/ions/molecules for example each corner of atom represents $1 / 8$ atoms and that piece on the edge of the unit/atom/ions/molecules represents $1 / 4$ of atoms.

International Journal of Research -GRANTHAALAYAH 
The model allows the application of colour combinations for better visualization relationship between crystal structures. It fosters to get the conceptual understanding in two dimensional and three dimensional unit cell and crystal lattices and identifies and locates unit in crystal lattices. It also provides knowledge, skill, competence, conceptual understanding of atomic structure, packing efficiency among the different unit cells and crystal lattices types. It fosters the knowledge, skill, competence, conceptual understanding of finding empirical formula with the help of unit cell and coordination number. The students of the study group are taught Chemistry of solid state by using computer based animation of crystal lattice and unit cell as teaching aid. The students of the control group are taught by using traditional (chalk and talk) method. The treatment lasts for two weeks and 45 minutes duration for 25 periods.
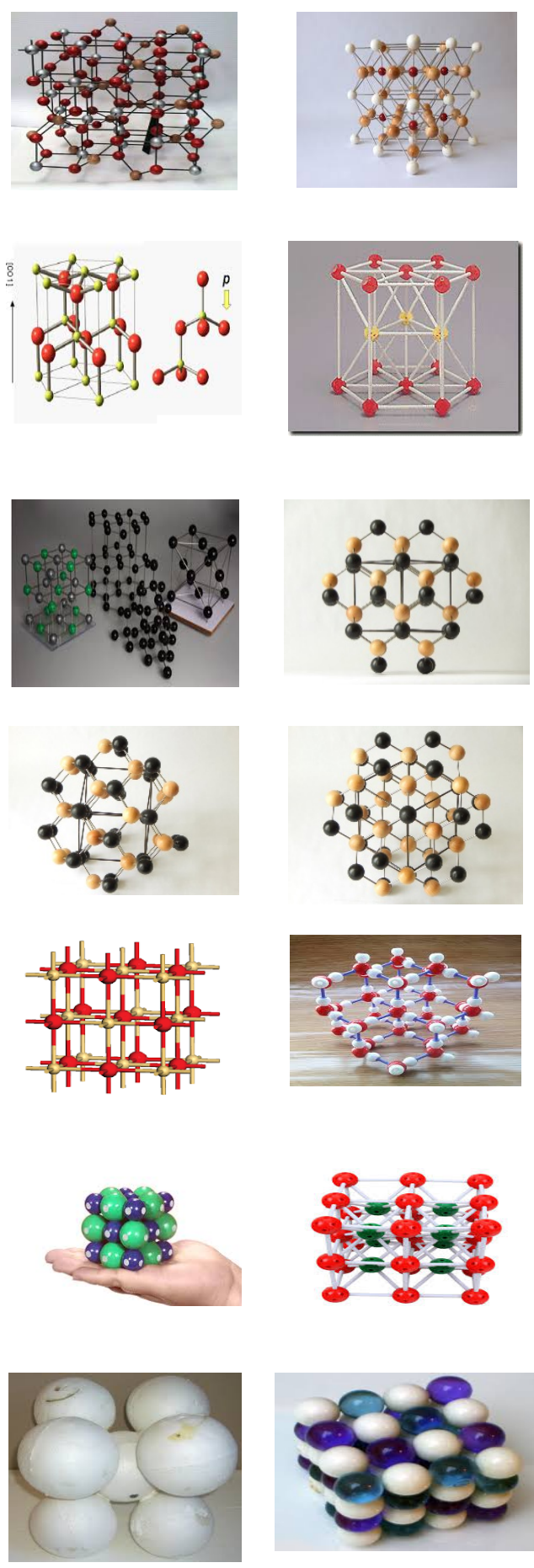
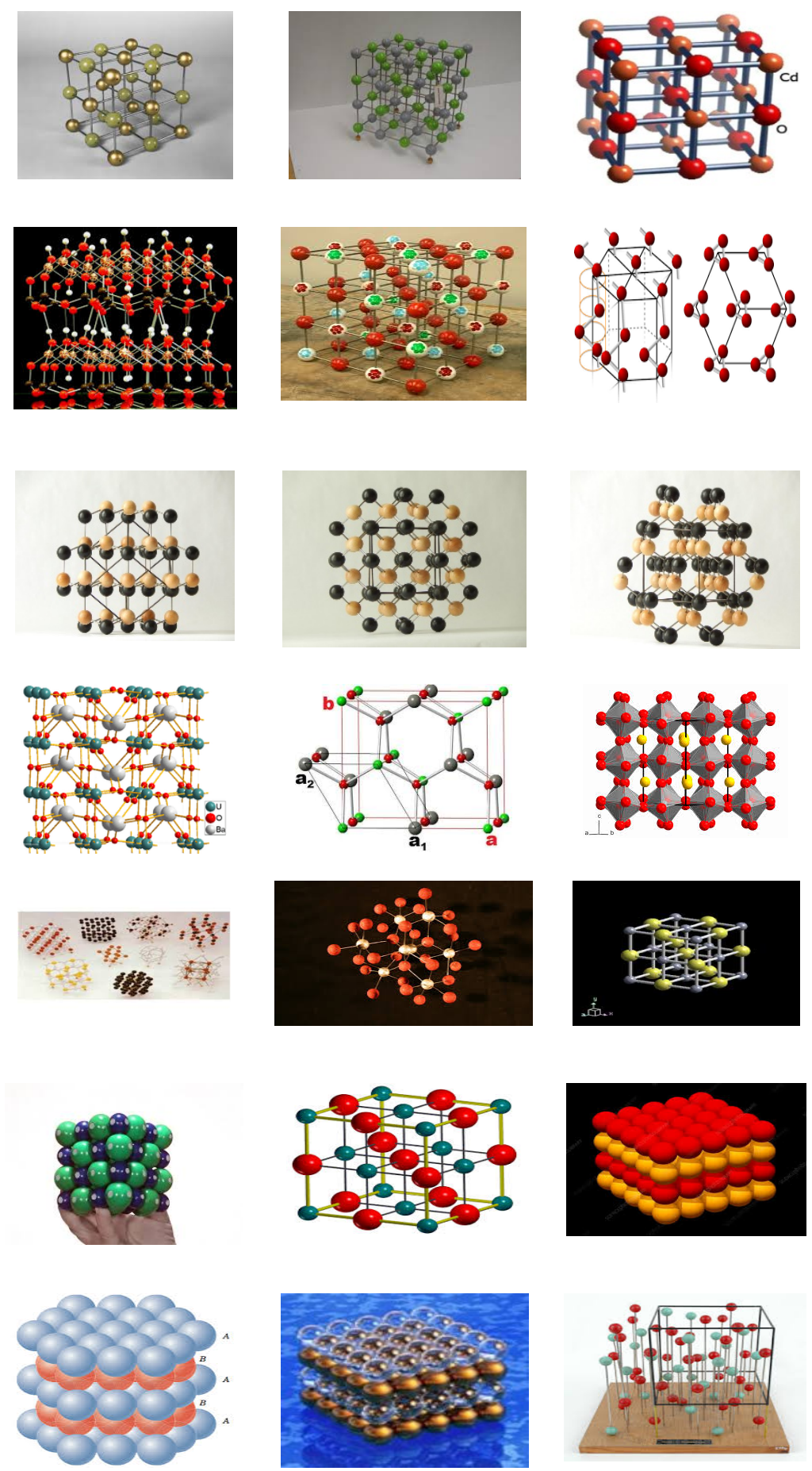

Figure 1: Different Models 


\section{METHODS}

\section{Research design}

In the present research quantitative approach with the type of experimental research (quasi experiment) is applied.

\section{Sample}

Totally 60 students participate in the study. All students are from Grade 12 studying Chemistry as elective subject. Students are divided into two groups (study group and control group). Each group consists of 30 students.

\section{Tool}

The test is conducted before and after the treatment for the collection of data. The content validity is done by using an expert opinion. Reliability is done by using alpha-Cronbach and value is 0.92 .

\section{Data analysis}

The data is collected by using test (previously and after) the treatment and are analyzed by using t-test by taking into the consideration of homogeneity and normality.

\section{RESULT AND DISCUSSIONS}

Table 1: Comparison of test data (before and after) treatment

\begin{tabular}{|c|c|c|c|c|}
\hline Data & \multicolumn{2}{|c|}{ Before treatment } & \multicolumn{2}{c|}{ After treatment } \\
\hline & Study Group & Control Group & Study Group & Control Group \\
\hline $\mathrm{N}$ & 30 & 30 & 30 & 30 \\
\hline Highest Score & 88 & 80 & 96 & 82 \\
\hline Lowest Score & 62 & 32 & 66 & 54 \\
\hline Mean & 75 & 66 & 81 & 68 \\
\hline
\end{tabular}

Table 2: Summary of normality test - result data (before and after) treatment

\begin{tabular}{|c|c|c|c|c|c|c|}
\hline Data & Test & $\mathrm{N}$ & Sig. (\%) & $\begin{array}{c}\text { Significance } \\
\text { (2 trailer) }\end{array}$ & Criteria & Description \\
\hline Study Group & \multirow[t]{2}{*}{ Before the treatment } & 30 & 5 & 0.201 & $p>0.05$ & Sig $0.201>0.05$ \\
\hline Control Group & & 30 & 5 & 0.107 & $\mathrm{p}>0.05$ & Sig 0.107>0.05 \\
\hline Study Group & \multirow[t]{2}{*}{ After the treatment } & 30 & 5 & 0.183 & $p>0.05$ & Sig $0.183>0.05$ \\
\hline Control Group & & 30 & 5 & 0.201 & $\mathrm{p}>0.05$ & Sig $0.201>0.05$ \\
\hline
\end{tabular}

Table 3: Summary of test results Homogeneity (before treatment)

\begin{tabular}{|c|c|c|c|c|}
\hline Data & Level of statistics & Df & $\begin{array}{c}\text { Sig } \\
(2 \text { trailer })\end{array}$ & Results \\
\hline Before the treatment & 0.614 & 58 & 0.438 & Sig $0.438>0.05$ homogenous \\
\hline After the treatment & 0.247 & 58 & 0.623 & Sig $0.623>0.05$ homogenous \\
\hline
\end{tabular}

Table 4: Summary of result t-test data (before and after treatment) study group

\begin{tabular}{|c|c|c|c|c|c|}
\hline Data & $\mathrm{t}$ & $\mathrm{Df}$ & Sig (2 trailer) & Description & Results \\
\hline Before and after the treatment & -0.623 & 30 & 0.000 & Sig $<0.005$ & $0.000<0.05$ \\
\hline
\end{tabular}

Table 5: Summary of result t-test data (before and after treatment) control group

\begin{tabular}{|c|c|c|c|c|c|}
\hline Data & $\mathrm{t}$ & Df & Sig (2 trailer) & Description & Results \\
\hline Before and after the treatment & -1.188 & 29 & 0.250 & Sig $>0.005$ & $0.250>0.05$ \\
\hline
\end{tabular}

Table 6: Summary of result t-test data (after treatment) study group and control group

\begin{tabular}{|c|c|c|c|c|c|}
\hline Data & $\mathrm{t}$ & $\mathrm{Df}$ & Sig (2 trailer) & Description & Results \\
\hline Before and after the treatment & $\mathrm{a} .675$ & 58 & 0.011 & Sig $<0.005$ & $0.011>0.05$ \\
\hline
\end{tabular}


Result (Table 1) reveals that there is an increase in the average score of six in the study group and two in the control group. The significant difference in score of two groups is four. The data is also tested for normality and homogeneity. As per the result (Table 2) reveals that significant ( 2 tailed) of the data of test conducted before and after the treatment of study and control group is higher than 0.05 . Hence data has normal distribution and eligible for analysis. Data is further tested for homogeneity (Table 3). The value of significant ( 2 tailed) of the data of test conducted before and after the treatment is higher than 0.05 . Hence it is concluded that both group comes from the same variance.

Data analysis is done to test the study hypothesis by using t- test of test conducted before and after the treatment for both groups to determine the initial capabilities of both groups. t- Test of test conducted after the treatment is to find second end ability of the both groups (study and control) (Table 4). The value of $t$ is -1.188 and significant with $p(p>0.05)$. There is noteworthy difference in the result of test conducted before and after the treatment of study group.

The result of t-test data for the test conducted before and after the treatment for control group is shown in Table 5 . The value of " $t$ " is -1.88 significant with $p(p>0.05)$. The result of the t-test reveals that there is no noteworthy difference of the test conducted before and after the treatment in solid state Chemistry. The result of the t-test on the ability to find coordination number, packing efficiency, number of atom of unit cell, ability to design two dimensional and three dimensional structures (unit cell and crystal lattice) and intended outcome of learning is shown in Table 6. The calculated $t-$ value is 2.675 and significant with $p(p>0.05)$. Hence it is proved that there is a noteworthy difference on the impact of evidence based learning to design and fabricate animated model in solid state Chemistry.

\subsection{DISCUSSION}

The positive effect of the model designed with the help of the computer as a teaching tool for the classroom instruction can be seen from the result of the t-test. The t-test showing value 2.675 and significant with $p(p>0.05)$

The computer based model of the solid state Chemistry has significant influence on the ability to perform in conceptual understanding knowledge gain, skill acquired and competence applied.

The model is based on sight, hearing and touch to satisfy the requirement of all three kinds of learners- auditory, visual and kinetics. Such model accumulate the learning style of students and hence applied in the classroom instructions as teaching aid which is effective and efficient to enhance the academic achievement of the students. In the present paper proposed model fosters the improvement of academic performance in terms of knowledge, skill and competence.

\section{CONCLUSION}

The computer based model on solid state chemistry is effective and it enhances the conceptual understanding, knowledge gained, skills acquired and competence applied. It is proved by the t-test obtained 2.275 and significant with $p>0.005$. Based on the result computed the present class room strategy is effective and efficient as compared to the conventional method applied for the Chemistry of solid state. Hence it may be replicated for other units of same and other core subjects.

\section{SOURCES OF FUNDING}

This research received no specific grant from any funding agency in the public, commercial, or not-for-profit sectors.

\section{CONFLICT OF INTEREST}

The author have declared that no competing interests exist. 


\section{ACKNOWLEDGMENT}

None.

\section{REFERENCES}

[1] Prashant Thote, Experiential Learning: Inclusive Art Education for Joyful Learning, Review of Research, Vol 8, Issue- 09, June 2019.

[2] Prashant Thote, Experiential Learning: Model for Teaching Science at Grade Nine, Research Magma, Vol-3, Issue -06, August - 2019.

[3] Prashant Thote, An Analysis of Impact of Evidence Based Learning on Academic Achievement of Students, International Journal of Research- Granthaalayah, Vol 8, Issue- 08, August 2020.

[4] Prashant Thote, Experiential Learning: An Analysis of Impact on Academic Achievement Among Students of Grade 12, International Journal of Research- Granthaalayah, Vol 8, Issue- 09, September 2020.

[5] Prashant Thote, Evidence Based Learning: An Analysis of Impact on Retention of Knowledge, International Journal of Research- Granthaalayah, Vol 8, Issue- 10, October 2020. 